\title{
Inhibitory Effect of Sargauum fulvellum Ethanolic Extract on LPS- Induced Inflammatory Reaction in RAW 264.7 Mouse Macrophages
}

\author{
Min-Ji Kim • Koth-Bong-Woo-Ri Kim • Da-Hyun Jeong • Dong-Hyun Ahn*
}

Received: 12 July 2013 / Accepted: 14 September 2013 / Published Online: 31 December 2013

(C) The Korean Society for Applied Biological Chemistry 2013

\begin{abstract}
Recently, algae has been considered as a potential antiinflammatory source due to its distinctive habitat environment exposing to light and high oxygen concentration. In present study, anti-inflammatory effect of brown alga, Sargassum fullvellum ethanol extract (SFEE), was examined. SFEE inhibited not only the production of nitric oxide and pro-inflammatory cytokines (IL-6, IL-1 $\beta$, TNF- $\alpha$ ) but also the expression of inducible nitric oxide synthase and cyclooxygenase 2 in LPS-induced RAW 264.7 cells without affecting cell viability. SFEE also suppressed the expression of nuclear factor kappa B (NF-kB), suggesting that SFEE could affect the expression of inflammation related cytokines and proteins through the regulation of NF- $\mathrm{BB}$. Furthermore, formation of edema of the ear was $40 \%$ lower in mice treated with the highest dose $(250 \mathrm{mg} / \mathrm{kg})$ of SFEE than in the control mice. Thus, our study showed that SFEE may be a potential therapeutic anti-inflammatory drug.
\end{abstract}

Keywords cyclooxygenase $2 \cdot$ ear edema $\cdot$ inducible nitric oxide synthase $\cdot$ nuclear factor kappa B $\cdot$ pro-inflammatory cytokines

\section{Introduction}

Inflammation is the result of the immune response of the host to pathogenic stimuli or tissue damage, and activated macrophages such as RAW 264.7 cells are involved in the process of inflammation (Kaplanski et al., 2003). The inflammatory process is initiated by complicated processes generated by microbial

D. -H. Jeong $\cdot$ D. -H. Ahn

Department of Food Science \& Technology/Institute of Food Science, Pukyong National University, Busan 608-737, Republic of Korea

M. -J. Kim · K. -B. -W. -R. Kim

Institute of Fisheries Sciences/Pukyong National University, 474, Ilgwangro, Ilgwang-myeon, Gijang-gun, Busan 619-911, Republic of Korea

*Corresponding author (D. -H. Ahn: dhahn@pknu.ac.kr) pathogens, such as lipopolysaccharides (LPS), which is a prototypical endotoxin (Corriveau and Danner, 1993). LPS directly activates macrophages, which are typical inflammatory cells and play a critical role in the inflammatory reaction. Activated macrophages produce increased amounts of nitric oxide (NO), prostaglandins, and cytokines such as interlukin-1 beta (IL-1 $\beta$ ), IL-6, and tumor necrosis factor alpha (TNF- $\alpha$ ) (Watson et al., 1999; Kubes and McCafferty, 2000). Other important inflammatory mediators include inducible nitric oxide synthase (iNOS) and cyclooxygenase 2 (COX-2) enzymes (Van et al., 1994). iNOS is highly upregulated by LPS in macrophages, and activation of iNOS induces excessive release of NO (Esposito and Cuzzocrea, 2007). COX-2 is produced in macrophages and endothelial cells in response to bacterial lipopolysaccharides and proinflammatory cytokines and may be related to the edema and vasodilatation associated with inflammation. $\mathrm{PGE}_{2}$ is produced from arachidonic acid metabolites by the catalysis of COX-2 (Murakami and Ohigashi, 2007). Activation of the nuclear factor kappa B (NF- $\mathrm{B}$ ) plays a major role in inflammation by regulating genes encoding inflammation-related molecules such as iNOS and COX-2 (Lowenstein et al., 1993). $\mathrm{NF}-\mathrm{\kappa B}$ is a transcription factor that consists of p50 and p65 (Rel family) and exists in the cytosol bound to the inhibitory protein

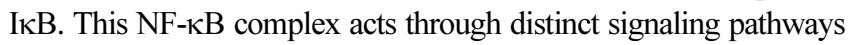
that finally lead to the activation of I $\mathrm{KB}$ kinase (IKK). IKK initiates $\mathrm{I} \kappa \mathrm{B}$ phosphorylation at specific amino-terminal serine residues and is activated in response to cell stimulation by TNF$\alpha$, IL-1, and LPS (Rothwarf et al., 1998). Thus, pharmacological reduction in the levels of LPS-inducible inflammatory mediators is one of the essential conditions to alleviate various disorders caused by activation of macrophages (Kim et al., 2008).

Currently, the development of natural anti-inflammatory drugs for prevention or treatment inflammatory diseases is receiving increasing attention. In particular, marine organisms are great sources of structurally diverse bioactive compounds with various biological activities. Seaweed is one of the valuable resources, which can be used as anti-inflammatory drugs, and many researchers have reported the anti-inflammatory effect of compounds originated from marine algae, such as polysaccharides 
(Wijesekara et al., 2011) and polyphenols like phlorotannins (Wijesekara et al., 2010). In addition, the bioactive compounds like alginic acid, laminarin, iodine, and fucoidin from brown seaweed are well known to inhibit or prevent a variety of inflammatory diseases by suppressing the secretion of inflammatory mediators in activated macrophages (Li et al., 2011). Sargassum is tropical and sub-tropical brown algae comprising 150 species, common to all oceans except Antarctica (Dar et al., 2007). Sargassum have been studied extensively, and polysaccharides extracted from different Sargassum algae such as $S$. dentifolium (Amira et al., 2013), S. wightii (Josephine et al., 2008), S. thunbergii and others (Kang et al., 2008) were reviewed and showed the diverse bioactivities such as anti-oxidant, antiinflammatory, anti-genotoxic, and anti-cancer. However, the mechanisms underlying the anti-inflammatory properties of the ethanol extract of Sargauum fulvellum (S. fulvellum) are yet to be established.

S. fulvellum, an edible brown alga, is collected from the coast of Korea. Despite its abundant resources of $S$. fulvellum, only anticancer, antibacterial, and antioxidant properties of $S$. fulvellum have been reported to date (Bae, 2004). Further studies are required to determine the potential anti-inflammatory activities of S. fulvellum and its application in food and pharmaceutical products. Therefore, in this study, we investigated the antiinflammatory effect of $S$. fulvellum ethanol extract (SFEE) by evaluating the inflammation mediated cytokines and proteins in vitro test. Also, in vivo studies, the formation of ear edema was assessed to investigate the inhibitory effect of SFEE in an animal model. Our results provide the basis of inhibitory effects of SFEE through the regulation of $\mathrm{NF}-\kappa \mathrm{B}$.

\section{Materials and Methods}

Chemicals. Specific antibodies against $\beta$-actin, COX-2, iNOS, NF- $\kappa \mathrm{B}$ p65, and anti-mouse immunoglobulin G-conjugated horseradish peroxidase were obtained from Santa Cruz (USA). LPS, dimethylsulfoxide (DMSO), and 3-(4,5-dimethylthiazol-2yl)-2,5-diphenyltetrazolium bromide (MTT) reagents were purchased from Sigma (USA). Enzyme-linked immunosorbent assay (ELISA) kits for TNF- $\alpha$, IL-6, and IL-1 $\beta$ were purchased from BD Biosciences (USA) and Dulbecco's Modified Eagle's Medium (DMEM) was from GIBCO (USA). Fetal bovine serum (FBS) and penicillin/streptomycin were purchased from Hyclone (USA), and BCA protein assay kit and enhanced chemiluminescence kit (ECL kit) were from Pierce (USA).

Preparation of SFEE. S. fulvellum was collected along the Chung-Sa-Po coast of Korea in March 2008. The dried powder was extracted with $80 \%$ ethyl alcohol at room temperature using a stirrer (H-0820; Dongwon Science Co., Korea). Then, the extracts were centrifuged at $2,090 \times g$ for $10 \mathrm{~min}$, and the supernatant was filtered and the filtrate was evaporated to remove the solvent under reduced pressure at a temperature lower than $40^{\circ} \mathrm{C}$ by using a rotary evaporator (RE 200; Yamato Co., Japan). The concentrate was dried at $37^{\circ} \mathrm{C}$ to completely remove extraction solvent, and was stored at $-20^{\circ} \mathrm{C}$ before use. The yield of final extract was $20.54 \%$.

Cell culture. The murine macrophages RAW 264.7 were purchased from the Korean Cell Line Bank (KCLB 40071, Korea). RAW 264.7 cells were maintained in DMEM supplemented with $10 \%$ FBS and $1 \%$ penicillin/streptomycin at $37^{\circ} \mathrm{C}$ in an atmosphere of $5 \% \mathrm{CO}_{2}$.

MTT assay for measuring cell viability. MTT was used as an indicator of cell viability, which was determined on the basis of mitochondrial-dependent reduction of MTT to formazan. Briefly, the cells were seeded and treated with the indicated concentration of SFEE $(0.001,0.1,1.10,50$, and $100 \mu \mathrm{g} / \mathrm{mL})$ with LPS $(1 \mu \mathrm{g} /$ $\mathrm{mL}$ ) for $22 \mathrm{~h}$, and then incubated with a solution of $5 \mathrm{mg} / \mathrm{mL}$ MTT for the next $2 \mathrm{~h}$. After the supernatant was removed, the formazan was dissolved in DMSO. It was observed at $540 \mathrm{~nm}$ using a microplate reader (Model 550; Bio-rad, USA).

Assay for nitrite by activated macrophages. The concentration of NO in the culture supernatant was determined as nitrite, a major stable product of NO, using the Griess reagent as described previously (Corker and Laurent, 1998). RAW 264.7 cells $(2.5 \times$ $10^{5}$ cells $\left./ \mathrm{mL}\right)$ were stimulated in 24-well plates with LPS $(1 \mu \mathrm{g} /$ $\mathrm{mL}$ ) and test extract for $24 \mathrm{~h}$. Then, $100 \mu \mathrm{L}$ of culture medium from each well was mixed with the same volume of the Griess reagent $(1 \%$ sulfanilamide $+0.1 \%$ naphthylendiamine dihydrochloride in 5\% phosphoric acid, 1:1). The nitrite level was evaluated colorimetrically at $540 \mathrm{~nm}$ using a microplate reader, and the nitrite concentration was calculated with reference to a standard curve of sodium nitrite generated using a known concentration.

ELISA. The levels of TNF- $\alpha$, IL- 6 , and IL- $1 \beta$ were determined using an ELISA kit (Mouse ELISA set; BD Bioscience). Briefly, RAW 264.7 cells $\left(2.5 \times 10^{5}\right.$ cells $\left./ \mathrm{mL}\right)$ were stimulated in 24-well plates with LPS $(1 \mu \mathrm{g} / \mathrm{mL})$ and indicated concentration of extracts for $24 \mathrm{~h}$. Then, levels of TNF- $\alpha$, IL-6, and IL-1 $\beta$ in the culture medium were measured by ELISA using anti-mouse TNF- $\alpha$, IL6 , and IL-1 $\beta$ antibodies and biotinylated secondary antibody according to the manufacturer's instruction.

Immunoblotting. Cells were lysed in the buffer containing 50 $\mathrm{mM}$ HEPES (pH 7.4), $150 \mathrm{mM} \mathrm{NaCl}, 5 \mathrm{mM}$ EDTA, $1 \%$ deoxycholate, $5 \mathrm{mM}$ phenylmethylsulfonyl fluoride, $1 \mu \mathrm{g} / \mathrm{mL}$ aprotinin, $1 \%$ Triton X-100, and 0.1\% NP-40. Cell lysates were centrifuged at $12,000 \mathrm{rpm}$ for $20 \mathrm{~min}$ to remove debris. Equal amounts of protein were separated on $10 \%$ sodium dodecyl sulfate-polyacrylamide minigels and transferred to polyvinylidene difluoride (PVDF) membranes (Bio-rad). The PVDF membranes were blocked with $5 \%$ skim milk (Fluka, Switzerland) in Trisbuffered saline containing $0.1 \%$ Tween 20 (TBST) buffer for $2 \mathrm{~h}$ and then incubated with anti-mouse iNOS, anti-mouse COX-2,

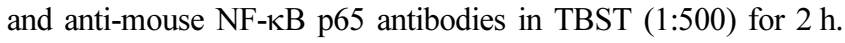
After washing 3 times with TBST, the membranes were incubated for $1 \mathrm{~h}$ with a secondary antibody conjugated to horseradish peroxidase (1:2000). After 3 washes in TBST, immunoreactive bands were visualized using the ECL detection system and were exposed to a radiographic film (Kodak X-Omat blue film, 


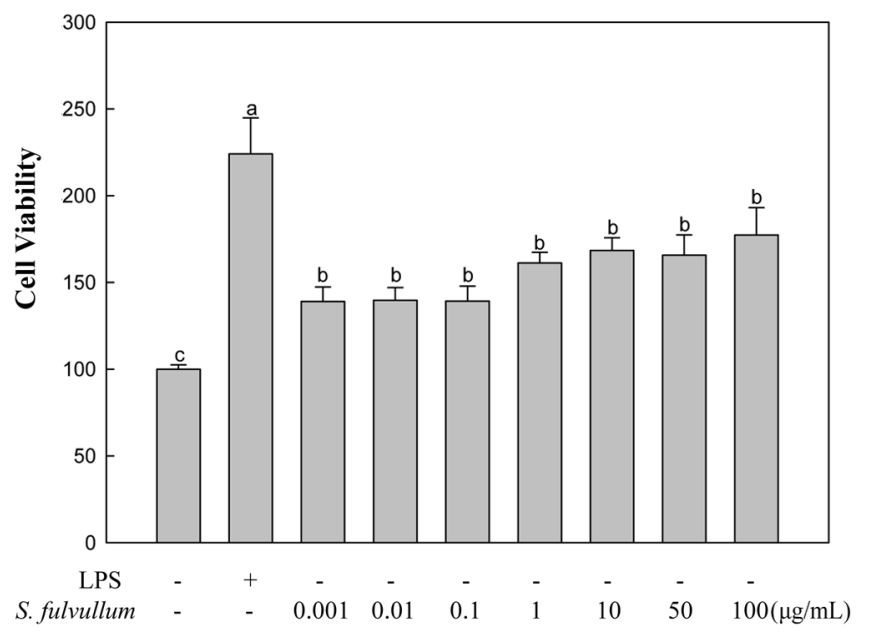

Fig. 1 Effect of Sargassum fulvellum ethanol extracts on the proliferation of RAW 264.7 cells. RAW 264.7 cells $\left(1 \times 10^{5}\right.$ cells $\left./ \mathrm{mL}\right)$ were pre incubated for $20 \mathrm{~h}$, and then treated with SFEE $(0.001,0.01,0.1,1,10$, $50,100 \mu \mathrm{g} / \mathrm{mL}$ ) for $24 \mathrm{~h}$. The viability of macrophages on SFEE was determined by MTT assay. The data indicate a means \pm SD of three independent experiments. The different letters indicate significant differences determined by Duncan's multiple range test $(p<0.05)$. Cell viability $=$ sample O.D/ control O.D*100.

PerkinElmer, Waltham, USA). The signal intensity of each protein bands was measured by densitometry, employing the Gene Tools from Syngene software.

Acute oral toxicity test. BALB/c mice (10-week-old, 20-25 g body weight) were used in an acute toxicity test. The animals were maintained at room temperature $\left(22 \pm 1^{\circ} \mathrm{C}\right)$ under a 12 -h light/12-h dark cycle with free access to food and water. Right before the acute toxicity test, mice were fasted for $6 \mathrm{~h}$ with water provided ad libitum. SFEE $(5 \mathrm{~g} / 10 \mathrm{~mL}$ of $5 \%$ tween- $80 / \mathrm{kg}$ body weight) was administered orally to the mice $(n=5)$. Then, the animals were observed for any abnormal behavior for $6 \mathrm{~h}$, and mortality was noted for up to 2 weeks. A group of animals treated with $5 \%$ tween- 80 served as control.

In vivo anti-inflammatory activity. To investigate the inhibitory effect of SFEE in an animal model of inflammation, we performed an assay to determine croton oil-induced ear edema in mice using the following procedure. Briefly, male ICR mice (8-week-old, 20 $25 \mathrm{~g}$ body weight) were used, and the animals were housed at $22 \pm 1{ }^{\circ} \mathrm{C}$ on a 12-h light/12-h dark cycle with free access to food and water. We topically applied $2.5 \%$ croton oil dissolved in acetone $(20 \mu \mathrm{L} / \mathrm{ear})$ to the inner and the outer surfaces of ear. One hour before treatment with croton oil, SFEE was orally administered to mice. Ear thickness was measured $5 \mathrm{~h}$ after croton oil treatment, and increase in thickness after croton oil treatment was considered as formation of edema. Prednisolone, commonly employed and useful agents to treat the inflammatory disorders, was used as a reference steroidal anti-inflammatory drug in this study (Chiu et al., 2010).

Statistical analysis. Differences between conditions were assessed by analysis of variance (ANOVA) according to Duncan's multiple

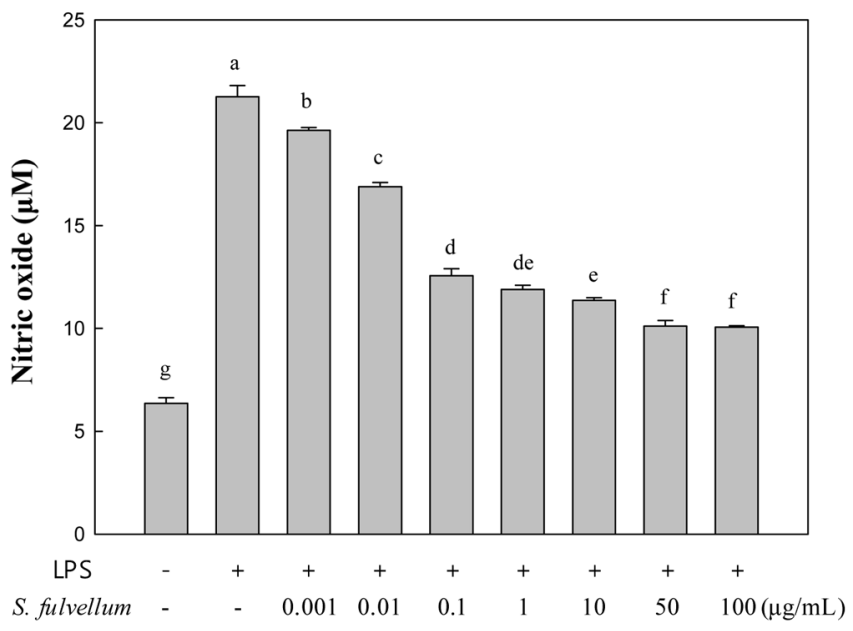

Fig. 2 Inhibitory effect of Sargassum fulvellum ethanol extracts on the production of NO in RAW 264.7 cells. The production of NO was measured in the culture medium of macrophages stimulated with LPS (1 $\mu \mathrm{g} / \mathrm{mL})$ for $24 \mathrm{~h}$ in the presence of SFEE $(0.001,0.01,0.1,1,10,50,100$ $\mu \mathrm{g} / \mathrm{mL}$ ). The data indicate a means $\pm \mathrm{SD}$ of three independent experiments. The different letters indicate significant differences determined by Duncan's multiple range test $(p<0.05)$.

range test $(p<0.05)$ by using the SAS software (SAS Institute Inc., USA). The data indicate means $\pm \mathrm{SD}$ of three independent experiments.

\section{Results and Discussion}

Effects of SFEE on cell viability. In order to evaluate the effect of SFEE on a proliferation of RAW 264.7 cells, the MTT assay was carried out. Our results showed that SFEE up to $100 \mu \mathrm{g} / \mathrm{mL}$ has not adverse effects. Although cell viability tended to be increased in all concentrations, it was not as much as that in the control (Fig. 1). Thus, the anti-inflammatory reactions by SFEE were not affected by the cytotoxic effect.

Effects of SFEE on LPS-stimulated NO production. Large amounts of $\mathrm{NO}$ are produced under inflammatory stimuli and overproduction of NO can be harmful and may cause various inflammatory and autoimmune diseases (Berenbaum, 2000). Thus, we determined the effect of SFEE on the production of NO using the Griess assay. The secretion of NO in LPS-stimulated macrophages increased dramatically compared to that in the control, and the production of NO decreased in a dose-dependent manner after treatment with SFEE (Fig. 2). LPS-induced NO production was significantly inhibited, and it was reduced more than $50 \%$ at $50 \mu \mathrm{g} / \mathrm{mL}$ and $100 \mu \mathrm{g} / \mathrm{mL}$. In particular, SFEE showed an excellent inhibitory effect on NO production at a low concentration of $1 \mu \mathrm{g} / \mathrm{mL}$, up to $47 \%$ inhibition. Many studies have shown that fucoxanthin and fucoidan from brown alga effectively suppress NO production (Hoe et al., 2010). These results indicate that SFEE-induced inhibition of NO might be because of the active ingredients in the SFEE. Also, this result 


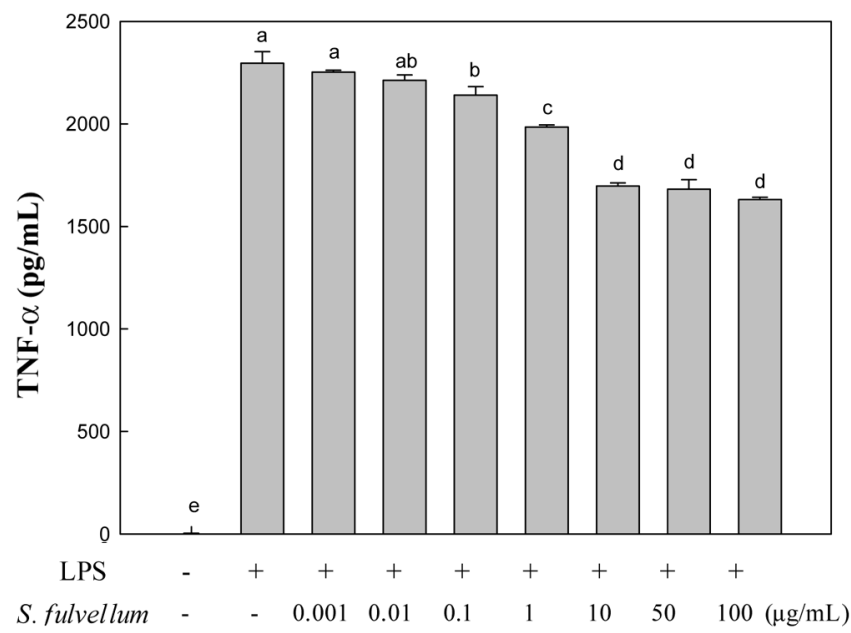

Fig. 3 Inhibitory effect of Sargassum fulvellum ethanol extracts on the production of TNF- $\alpha$ in RAW 264.7 cells. RAW 264.7 cells $\left(2.5 \times 10^{5}\right.$ cells $/ \mathrm{mL}$ ) were pre incubated for $18 \mathrm{~h}$ and then stimulated with LPS (1 $\mu \mathrm{g} / \mathrm{mL})$ for $24 \mathrm{~h}$ in the presence of SFEE $(0.001,0.01,0.1,1,10,50,100$ $\mu \mathrm{g} / \mathrm{mL})$. The production levels of TNF- $\alpha$ were measured in culture media using an ELISA kits. The data indicate a means \pm SD of three independent experiments. The different letters indicate significant differences determined by Duncan's multiple range test $(p<0.05)$.

could be related to that of iNOS expression showing decrease in a dose-dependent manner (Fig. 6).

Inhibition of LPS-induced TNF- $\alpha$, IL-6, and IL-1 $\beta$ productions by SFEE. TNF- $\alpha$, IL-6, and IL- $1 \beta$ are the most critical proinflammatory cytokines; we measured the inhibitory effect of SFEE on these mediators using ELISA. TNF- $\alpha$ is Th1 cytokine that has a wide range of actions in inflammation, infection, and immunity, and IL-1 $\beta$ is also major proinflammatory cytokine synthesized during the infection and inflammatory process (Prussin and Metcalfe, 2003). IL-6 is a protein secreted by Th2 cells and macrophages and plays an important role in immune response. IL- 6 regulates the proliferation and differentiation of $\mathrm{T}$ cells, and elicits immunoglobulin production in B cells (Chen et al., 2012). The RAW 264.7 cells were cultured in the media with LPS $(1 \mu \mathrm{g} / \mathrm{mL})$ alone or in combination with the extract. Our results showed that the production of the cytokines decreased in a dose-dependent manner after treatment with both LPS and SFEE, while the secretion of the cytokines increased significantly after treatment with LPS alone. In particular, a remarkable inhibition of IL- $1 \beta$ production was observed at $0.1 \mu \mathrm{g} / \mathrm{mL}$ and IL- 6 production decreased up to $50 \%$ at $50 \mu \mathrm{g} / \mathrm{mL}$ and $100 \mu \mathrm{g} / \mathrm{mL}$ (Fig. 3-5). These results are similar to those of $S$. micracanthum extract, which show that the production of proinflammatory cytokines decrease in a dose-dependent manner, and these results were caused by the phlorotannins in brown seaweed (Jung et al., 2009; $\mathrm{Li}$ et al., 2011). Thus, these results are consistent with those obtained in our study, and it suggested that SA-E extract could influence Th2 cell activation as well as Th1 cell activation.

Effect of SFEE on LPS-induced expression of iNOS and COX2 protein. iNOS plays an important role in the inflammatory

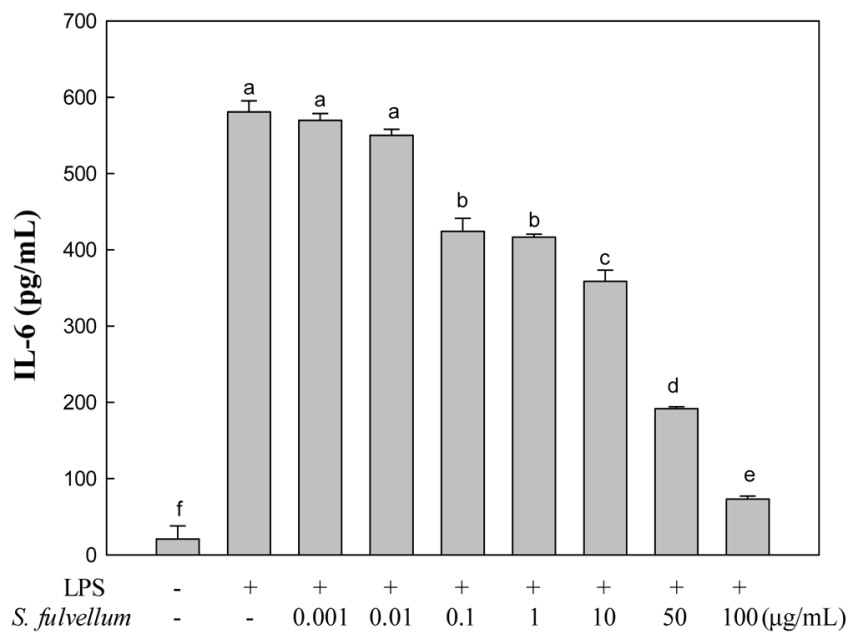

Fig. 4 Inhibitory effect of Sargassum fulvellum ethanol extracts on the production of IL-6 in RAW 264.7 cells. RAW 264.7 cells $\left(2.5 \times 10^{5}\right.$ cells/ $\mathrm{mL})$ were pre incubated for $18 \mathrm{~h}$ and then stimulated with LPS $(1 \mu \mathrm{g} / \mathrm{mL})$ for $24 \mathrm{~h}$ in the presence of SFEE $(0.001,0.01,0.1,1,10,50,100 \mu \mathrm{g} / \mathrm{mL})$. The production levels of IL- 6 were measured in culture media using an ELISA kits. The data indicate a means $\pm \mathrm{SD}$ of three independent experiments. The different letters indicate significant differences determined by Duncan's multiple range test $(p<0.05)$.

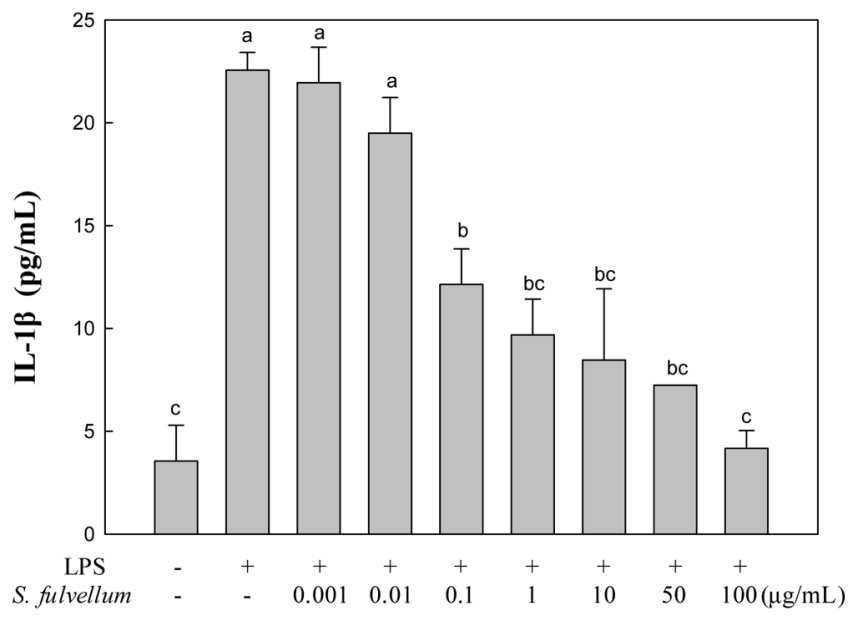

Fig. 5 Inhibitory effect of Sargassum fulvellum ethanol extracts on the production of IL-1 $\beta$ in RAW 264.7 cells. RAW 264.7 cells $\left(2.5 \times 10^{5}\right.$ cells $/ \mathrm{mL}$ ) were pre incubated for $18 \mathrm{~h}$ and then stimulated with LPS (1 $\mu \mathrm{g} / \mathrm{mL})$ for $24 \mathrm{~h}$ in the presence of SFEE $(0.001,0.01,0.1,1,10,50,100$ $\mu \mathrm{g} / \mathrm{mL})$. The production levels of IL- $1 \beta$ were measured in culture media using an ELISA kits. The data indicate a means \pm SD of three independent experiments. The different letters indicate significant differences determined by Duncan's multiple range test $(p<0.05)$.

reaction by producing excessive NO (Renard and Raes, 1999). iNOS is involved in complex biological processes and is a wellknown host innate immune and inflammatory response to diverse pathogens (Wallace, 2005). COX-2 is another important enzyme induced by several stimuli such as LPS, cytokines, and growth factors and is expressed in response to inflammation. Also, COX2 is related to the synthesis and production of $\mathrm{PG}$, which regulates 


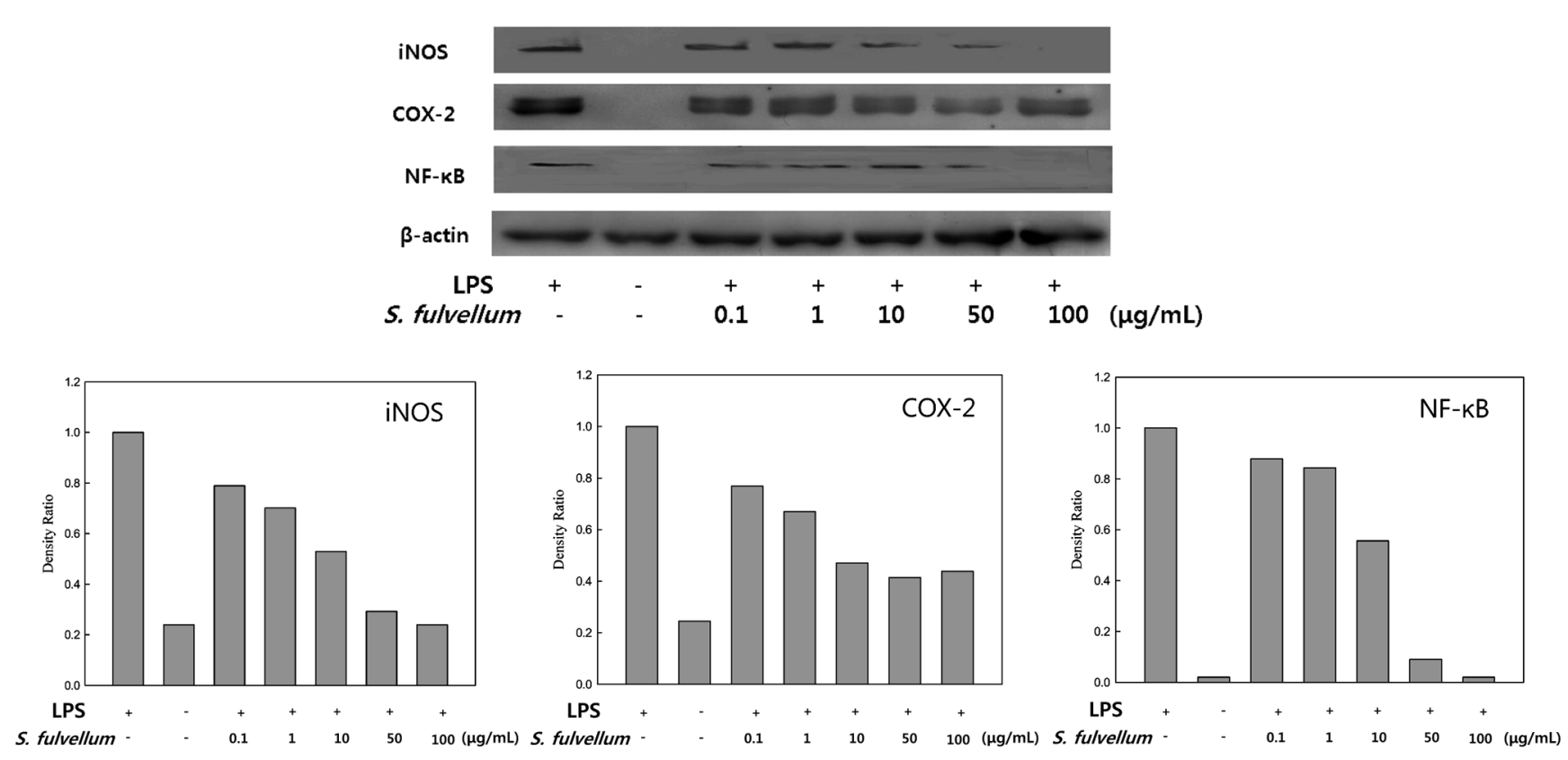

Fig. 6 Inhibitory effects of Sargassum fulvellum ethanol extract on the protein expression of iNOS, COX-2, and NF-kB in RAW 264.7 cells. RAW 264.7 macrophages $\left(2.5 \times 10^{5}\right.$ cells $\left./ \mathrm{mL}\right)$ were preincubated for $18 \mathrm{~h}$, and then simulated with LPS $(1 \mu \mathrm{g} / \mathrm{mL})$ for $24 \mathrm{~h}$ in the presence of SFEE $(0.1,1$, $10,50,100 \mu \mathrm{g} / \mathrm{mL}$ ). Cell lysates were electrophoresed and then expression levels of iNOS, COX-2 and NF- $\mathrm{kB}$ were detected with specific antibodies. Densitometrically calculated protein expression levels were given as a relative intensity of of iNOS/ $\beta$-actin, $C O X-2 / \beta$-actin and NF- $\mathrm{KB} / \beta$-actin.

inflammatory mediation (Jin et al., 2006). Therefore, we examined the inhibitory effect of SFEE on the expression of iNOS and COX-2 in macrophages (Fig. 6) using immunoblotting. The expression of iNOS and COX-2 protein was markedly increased in response to LPS alone, and the protein induction was inhibited in a dose-dependent manner after co-treatment with SFEE. In particular, the iNOS protein was not detected at $100 \mu \mathrm{g} / \mathrm{mL}$. The expression of iNOS and COX-2 has been revealed to be dependent on NF- $\kappa B$ activation (Baldwin, 1996). Thus, these results showed the possibility of SFEE in inhibiting the activity of NF- $\kappa B$.

Effect of SFEE on activation of NF- $\kappa \mathbf{B}$. Inflammation is caused by overproduction of proinflammatory cytokines and mediators induced by LPS in RAW 264.7 cells. Activation of NF- $\kappa B$, which is a major mechanism involved in the expression of proinflammatory cytokines and mediators (Shapira et al., 1996), is required for the release of these mediators. Because of the ubiquitous role of NF$\kappa \mathrm{B}$ as a transcription factor in the expression of inflammatory genes, NF- $\kappa \mathrm{B}$ is an important therapeutic target for various inflammatory diseases (Ahn et al., 2009). NO production by iNOS is also regulated primarily at the transcriptional level, and the expression of the iNOS gene in macrophages is controlled by several transcription factors as NF- $\mathrm{KB}$ (Bogdan, 2001). To determine whether SFEE affects the degradation of NF- $\mathrm{BB}$, we investigated the expression of NF- $\kappa$ B protein in macrophages. RAW 264.7 cells were cultured with LPS in the presence or absence of SFEE and then immunoblot analysis of the cell lysate was performed. Expression of NF- $\mathrm{KB}$ protein in the nucleus of the cells was diminished in a dose-dependent manner (Fig. 6). In addition, compared to LPS alone, treatment with $50 \mu \mathrm{g} / \mathrm{mL}$ of SFEE

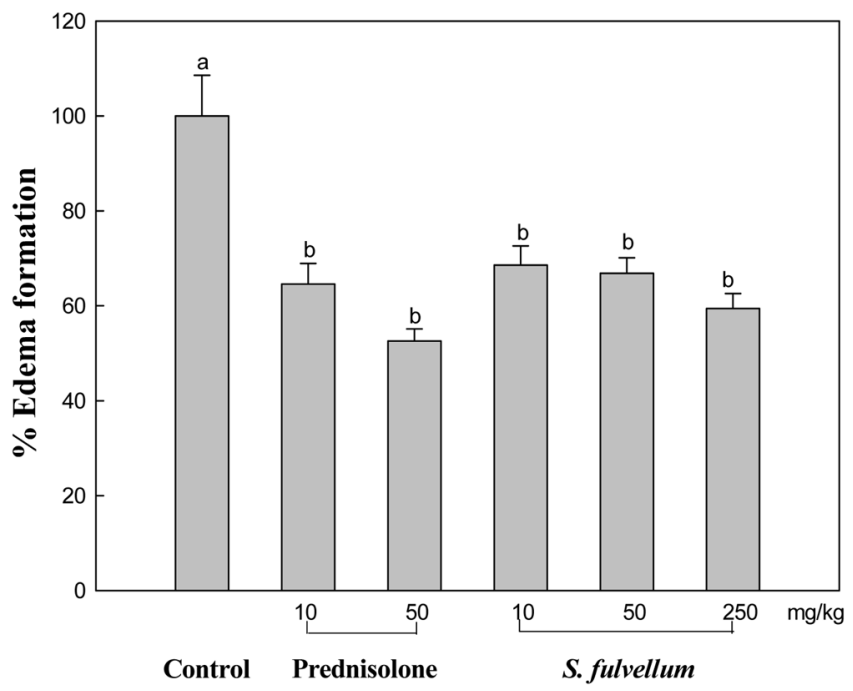

Fig. 7 Inhibition of Sargassum fulvellum ethanol extract against croton oil-induced mouse ear edema. The chronic inflammation process was induced by croton oil $(20 \mu \mathrm{L} / \mathrm{ear})$. SFEE and prednisolone were orally administered to mice, and the ear thickness was measured. The different letters indicate significant differences determined by Duncan's multiple range test $(p<0.05)$.

showed low amounts of NF- $\kappa B$, while treatment with $100 \mu \mathrm{g} / \mathrm{mL}$ showed no NF- $\kappa$ B.

SFEE significantly inhibited the expression of iNOS, COX-2 and production of proinflammaoty cytokines. This was most likely due to suppression of NF- $\mathrm{kB}$. After specific stimulation, 
Table 1 Mortality of BALB/c mice treated orally with Sargassum fulvellum ethanol extract

\begin{tabular}{|c|c|c|c|c|c|c|c|c|}
\hline & \multicolumn{8}{|c|}{ Days after treatment } \\
\hline & 0 & 2 & 4 & 6 & 8 & 10 & 12 & 14 \\
\hline Control & $0 / 5$ & $0 / 5$ & $0 / 5$ & $0 / 5$ & $0 / 5$ & $0 / 5$ & $0 / 5$ & $0 / 5$ \\
\hline $300 \mathrm{mg} / \mathrm{kg} \cdot$ body weight & $0 / 5$ & $0 / 5$ & $0 / 5$ & $0 / 5$ & $0 / 5$ & $0 / 5$ & $0 / 5$ & $0 / 5$ \\
\hline $2000 \mathrm{mg} / \mathrm{kg} \cdot$ body weight & $0 / 5$ & $0 / 5$ & $0 / 5$ & $0 / 5$ & $0 / 5$ & $0 / 5$ & $0 / 5$ & $0 / 5$ \\
\hline $5000 \mathrm{mg} / \mathrm{kg} \cdot$ body weight & $0 / 5$ & $0 / 5$ & $0 / 5$ & $0 / 5$ & $0 / 5$ & $0 / 5$ & $0 / 5$ & $0 / 5$ \\
\hline
\end{tabular}

such as TNF- $\alpha$ receptor triggering, I $\mathrm{KB}$ phosphorylation by IKKs leads to proteasome degradation of $\mathrm{I} \kappa \mathrm{B}$, releasing NF- $\mathrm{KB}$ to the nucleus. Once in the nucleus, NF- $\kappa \mathrm{B}$ modulates the transcription of innumerous gene (Rothwarf et al., 1998). Our results are consistent with the reports that NF- $\kappa \mathrm{B}$ response elements are present on the promoter for the iNOS, COX-2, and TNF- $\alpha$ gene (Chen et al., 1995). Therefore, this suggested that SFEE inhibition of LPS-induced expression of iNOS, COX-2, and proinflammatory cytokine genes occur through blocking of NF- $\mathrm{BB}$ activation.

Acute oral toxicity test. The acute oral toxicity test was performed to evaluate any toxic effects of the extracts in mice. Our results showed that no mortalities occurred in mice administered $5 \mathrm{~g} / \mathrm{kg}$ body weight of SFEE over the 2 weeks of observation. Mice administered SFEE responded by sleeping and wandering for $1 \mathrm{~h}$ and returned to normal behavior (Table 1). According to the WHO, an herbal medicine is considered toxic if its median lethal dose $\left(\mathrm{LD}_{50}\right)$ is lower than $5 \mathrm{~g} / \mathrm{kg}$ body weight (WHO, 1992). Thus, our results indicate that SFEE is not toxic and can be safely used by humans at moderate doses.

In vivo anti-inflammatory activity. To assess the effect of SFEE against acute inflammation, we performed croton oil-induced ear edema test in mice. Our results showed that the ear edema formation was decreased by $40 \%$ at the highest dose tested ( 250 $\mathrm{mg} / \mathrm{kg}$ ) compared to that in the control, while prednisolone, a reference steroidal anti-inflammatory drug, showed 36-48\% inhibition at 10 and $50 \mathrm{mg} / \mathrm{kg}$ (Fig. 7). This result suggested that the inhibitory activity of SFEE was similar to that of prednisolone, which indicates that SFEE has a potent anti-inflammatory effect.

In conclusion, these results showed that SFEE downregulated the expression of proinflammatory cytokines and mediators by suppressing NF- $\mathrm{KB}$ activation in RAW 264.7 cells, indicating a strong anti-inflammatory effect. The mouse ear edema test showed that SFEE reduced croton oil-induced mouse ear edema to an extent similar to that of the control. Furthermore, these results suggest that SFEE might influence the suppression of both $\mathrm{PGE}_{2}$ which is another inflammatory mediator generated by $\mathrm{COX}-2$ and $\mathrm{I} \kappa \mathrm{B} \alpha$ which activate degradation of NF- $\mathrm{KB}$ following its phosphorylation at the serine residue (Castrillo et al., 2000). Thus, these data provide the basis of the anti-inflammatory activity from natural resource and indicate its clinical use for inflammatory diseases.

Acknowledgments This research was financially supported by the Ministry of Trade, Industry and Energy (MOTIE) and Korea Institute for advancement of Technology (KIAT) through the Research and Development for Regional Industry.

\section{References}

Ahn YW, Lee SH, Choi YH, Kim SK, Yea SS, Choi I et al. (2009) Ecklonia cava ethanolic extracts inhibit lipopolysaccharide-induced cyclooxygenase2 and inducible nitric oxide synthase expression in BV2 microglia via the MAP kinase and NF-kB pathways. Food Chem Toxicol 47, 410-7.

Amira M, Gamal-Eldeen, Abo-Zeid Mona AM, and Eman F Ahmed (2013) Anti-genotoxic effect of the Sargassum dentifolium extracts: Prevention of chromosomal aberrations, micronuclei, and DNA fragmentation. Exp Toxicol Pathol 65, 27-34.

Bae SJ (2004) Anticarcinogenic effects of Sargassum fulvellum fractions on several human cancer cell lines in vitro. J Korean Soc Food Sci Nutr 33, 480-6.

Baldwin Jr AS (1996) NF-kappa B and I kappa B proteins: new discoveries and insights. Annu Rev Immuno 14, 649-83.

Berenbaum F (2000) Proinflammatory cytokines, prostaglandins, and the chondrocyte: mechanism of intracellular activation. Joint Bone Spine 67, $561-4$.

Bogdan C (2001) Nitiric oxide and the immune response. Nat Immunol 2, 907-16.

Castrillo A, Díaz-Guerra MJM, Hortelano S, Martín-Sanz P, and Boscá L

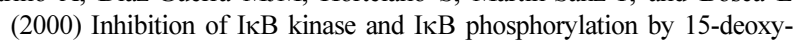
D12, 14-prostaglandin J2 in activated murine macrophages. Mol Cell Biol 20, 1692-8.

Chen F, Sun SC, Kuh DC, Gaydos LJ, and Demers LM (1995) Essential role of NF-kappa B activation in silica-induced inflammatory mediator production in macrophages. Biochem Bioph Res Co 214, 985-92.

Chen HH, Lin HT, Foung YF, and Lin JHY (2012) The bioactivity of teleost IL-6: IL-6 protein in orange-spotted grouper (Epinephelus coioides) induces Th2 cell differentiation pathway and antibody production. Dev Comp Immunol 38, 285-94.

Chiu CT, Chuang CY, Li JR., Huang HY, Chang SW, and Hung YC (2010) Greater therapeutic efficacy of prednisolone plus medicinal herbs than prednisolone or medicinal herbs alone in patients with oral lichen planus. J Dental Sci 5, 209-15.

Corker R and Laurent GJ (1998) Pulmonary fibrosis. Cytokines in the balance. Eur Respir J 11: 1218-21.

Corriveau CC and Danner RL (1993) Endotoxin as a therapeutic target in septic shock. Infect Agent Dis 2, 35-43.

Dar A, Baig HS, Saifuallah SM, Ahmad VU, Yasmeen N, and Nizamuddin M (2007) Effect of seaxonal variation on the anti-inflammatory activity of Sargassum sightii growing on the N. Arabian Sea coast of Pakistan. $J$ Exp Mar Boil Ecol 351, 1-9.

Esposito E and Cuzzocrea S (2007) The role of nitiric oxide synthases in lung inflammation. Curr Opin Invest Drugs 8, 899-909.

Hoe SJ, Yoon WJ, Kim KN, Ahn GN, Kang SM, Kang DH et al. (2010) Evaluation of anti-inflammatory effect of fucoxanthin isolated brown algae in lipopolysaccharide-stimulated RAW 264.7 macrophages. Food Chem Toxicol 48, 2045-51.

Jin DQ, Lim CS, Sung JY, Choi HG, Ha IH, and Han JS (2006) Ulva conglabata, a marine alga, has neuroprotective and anti-inflammatory effects in murine hippocampal and microglial cells. Neurosci Lett 402, 154-8.

Josephine A, Nithya K, Amudha G, Beena CK, Preetha SP, and Varalakshmi P (2008) Role of sulphated polysaccharides from Sargassum wightii in cyclosporine A-induced oxidative liver injury in rats. BMC Pharmacol $\mathbf{8}$, 
$4-13$.

Kang JY, Khan MN, Park NH, Cho JY, Lee MC, and Fujii H (2008) Antipyretic analgesic, and anti-inflammatory activities of the seaweed Sargassum fulvellum and Sargassum thunbergii in mice. J Ethnopharmacol 116, 187-90.

Kaplanski G, Marin V, Montero-Julian F, Mantovani A, and Farnarier C (2003) IL-6: A regulator of the transition from neutrophil to monocyte recruitment during inflammation. Trends Immunol 24, 25-9.

Kim YW, Zhao RJ, Park SJ, Lee JR, Cho IJ, Yang CH et al. (2008) Antiinflammatory effects of liquiritigenin as a consequence of the inhibition of NF- $\kappa \mathrm{B}-$ dependent iNOS and proinflammatory cytokines production. Br J Pharmacol 154, 165-73.

Kubes P and McCafferty DM (2000) Nitric oxide and intestinal inflammation. Am J Med 109, 150-8.

Li YX, Wijesekara I, Li Y, and Kim SK (2011) Phlorotannins as bioactive agents from brown algae. Process Biochem 46, 2219-24.

Lowenstein CJ, Alley EW, Rava Pl, Snowman AM, Snyder SH, Russell SWet al. (1993) Macrophage nitiric oxide synthase gene: Two upstream regions mediate induction by interferon gamma and lipopolysaccharide. Proc Natl Acad Sci USA 90, 9730-4.

Murakami A and Ohigashi H (2007) Targeting NO, iNOS and COX-2 in inflammatory cells: Chemoprevention using food phytochemicals. Int $J$ Cancer 121, 2357-63.

Prussin C and Metcalfe DD (2003) IgE, mast cells, basophils, and eosinophils. $J$ allergy Clin Immunol 111, S486-94.

Renard P and Raes M (1999) The proinflammatory transcription factor NF- $\kappa \mathrm{B}$ : A potential target for novel therapeutical strategies. Cell Biol Toxicol 115, 341-4.

Rothwarf DM, Zandi E, Natoli G, and Karin M (1998) IKK-gamma is an essential regulatory subunit of the IkappaB kinase complex. Nature 395, 297-300.

Shapira L, Soskolne WA, Houri Y, Barak V, Halabi A, and Stabholz A (1996) Protection against endotoxic shock and lipopolysaccharide-induced local inflammation by tetracycline: correlation with inhibition of cytokine secretion. Infect Immun 64, 825-8.

Van JR, Mitchell JA, Appleton I, Tomlinson A, Bishop-Bailey D, Croxtall J et al. (1994) Inducible isoforms of cyclooxygenase and nitiric-oxide synthase in inflammation. Proc Natl Acad Sci USA 91, 2046-50.

Wallace JL (2005) Nitric oxide as a regulator of inflammatory processes. Mem I Oswaldo Cruz 100: 5-9.

Watson WH, Zhao Y, and Chawla RK (1999) S-adenosylmethionine attenuates the lipopolysaccharide-induced expression of the gene for the tumour necrosis factor-a. Biochem J 342(Pt 1), 21-5.

WHO (1992) Research guidelines for evaluating the safety and efficacy of herbal medicine. Regional office for western pacific, Philiphines.

Wijesekara I, Pangestuti R, and Kim SK (2011) Biological activities and potential health benefits of sulfated polysaccharides derived from marine algae. Carbohydr Polym 84, 14-21.

Wijesekara I, Yoon NY, and Kim SK (2010) Phlorotannins from Ecklonia cava (Phaeophyceae): biological activities and potential health benefits. Biofactors 36, 408-14. 